\title{
Additional Testing Was Performed
}

National Cancer Institute

\section{Source}

National Cancer Institute. Additional Testing Was Performed. NCI Thesaurus. Code C160292.

An indication that additional tests were performed during the study. 